\title{
Creep Behaviour of the Polymer Composite with False Banana's Fibres (Ensete Ventricosum)
}

Čestmír Mizera, Petr Hrabě, Miroslav Müller, David Herák

Faculty of Engineering, Czech University of Life Sciences Prague. Czech Republic. E-mail: mizera@tf.czu.cz, hrabe@tf.czu.cz,muller@tf.czu.cz, herak@tf.czu.cz.

This study was focused on the analysis of creep behaviour of the polymer composite with continuous phase in the form of two-part epoxies and discontinuous phase (reinforcing particles) in the form of fibres of false banana (Ensete ventricosum). The aim of the experiment was to describe the short term flexural creep behaviour, flexural strength and Charpy impact strength of polymer composite reinforced by fibres of false banana. The fibres of Ensete ventricosum, originally from Ethiopian region Hawassa, were used for this experiment. Reinforcing fibres were prepared in size of length $\mathbf{1 - 2} \mathrm{mm}$ with randomly fibres arrangement in matrix. The amount of reinforcing particles in the composite material was $0.5 ; 2$ and $30 \mathrm{wt} . \%$. Moulds for casting specimens were produced from the material Lukapren $\mathrm{N}$ regarding to the prepared models whose shape corresponds to the technical standard CSN EN ISO 3167. Composite which was used to prepare specimens according to CSN EN ISO 3167 (Plastics - Multipurpose test specimens, English Standard Institution) was created by mixing of fixed rate of matrix and filler.

Keywords: agriculture, impact strength, flexural strength

\section{Acknowledgement}

This paper has been made with the assistance of the grant IGA TF CZU No. 2015:31130/1312/3104.

\section{References}

[1] ALVES, C., FERRARO, P.M.C., SILVA, A.J., REIS, L.G., FREITAS, M., RODRIGUES, L.B. (2010). Ecodesign of automotive components making use of natural jute fiber composites. Journal of Cleaner Production, 18, 313327.

[2] ACHA, B.A., REBOREDO, M.M., MARCOVICH, N.E. (2007). Creep and dynamic mechanical behavior of PPjute composites: Effect of the interfacial adhesion. Composites: Part A, 38, 1507 - 1516.

[3] AMUTHAKKANNAN, P., MANIKANDAN, V., WINOWLIN JAPPES, J.T., UTHAYAKUMAR, M. (2013). Effect of fibre length and fibre content on mechanical properties of short basalt fibre reinforced polymer matrix composites. Materials Physics and Mechanics, 16, 107-117.

[4] ASEER, J.R., SANKARANARAYANASAMY, K., JAYABALAN, P., NATARAJAN, R., DASAN, K.P. (2013). Morphological, Physical and Thermal Properties of Chemically Treated Banana Fiber. Journal of Natural Fibers, $10,365-380$.

[5] ASAE S410.1 DEC97. 1998. Moisture measurement of peanut. In: ASAE standards, 45th edition. 560-561.

[6] BLAHOVEC, J. (2008). Agromaterials - study Guide. Czech University of Life Sciences Prague, Prague.

[7] ČSN EN ISO 3167. 2004. Plastics - Multipurpose test specimens. In: Czech Standard Institution

[8] ČSN EN ISO 178. 2011. Plastics - Determination of flexural properties. In: Czech Standard Institution

[9] ČSN EN ISO 899-2. 2004. Plastics - Determination of creep behaviour - Part 2: Flexural creep by three-point loading. In: Czech Standard Institution

[10]DIRIBA, H.D., MAZANCOVÁ, J., RUŠAROVÁ, K., Havrland, B. (2013). Possibilities and Acceptance of Alternative Energies from Farm Solid Waste Material (Kocho): Case Study from Kembata Tenbaro Zone. EthiopiaTropentag 2013 International Research on Food Security, Natural Resource Management and Rural Development Agricultural development within the rural-urban continuum, Gottingen.

[11]FARUK, O., BLEDZKI, A.K., FINK, H.P., SAIN, M. (2012). Biocomposites reinforced with natural fibers: 20002010. Progress in Polymer Science, 37, 1552-1596.

[12]HARUN, J., ABDAN, K., ZAMAN, K. (2008). Rheological behaviour of injection moulded oil palm empty fruit bunch fiber-polypropylene composites: effects of electron beam processing versus maleated polypropylene. Molecular Crystals and Liquid Crystals Science, 484, 134-142.

[13]HERÁK, D., BLAHOVEC, J., KABUTEY, A. (2014). Analysis of the axial pressing of bulk Jatropha curcas L. seeds using reciprocal slope transformation. Biosystems Engineering, 121, 67 - 76. 
[14]HPSA, K., ISMAIL, H., ROZMAN, H.D., AHMED, M.N. (2001). The effect of acetylation on interfacial shear strength between plant fibers and various matrices. European Polymer Journal, 37, 1037-1045.

[15]JACKEL, M., SCHEIBNER, W. (1991). Boundary layer induced modification of thermal and mechanical properties of epoxy resin composites. Cryogenics, 31, 269-272.

[16] KALIA, S., THAKUR, K., CELLI, A., KIECHEL, M.A., SCHAUER, C.L. (2013). Surface modification of plant fibers using environment friendly methods for their application in polymer composites, textile industry and antimicrobial activities. Journal of Environmental Chemical Engineering, 1, 97-112.

[17]KELLER, A. (2003). Compounding and mechanical properties of biodegradable hemp fiber composites. Composite Science and Technology, 63, 1307-1316.

[18] KIM, J.H., LEE, H.J., LEE, H.S., LIM, E.J., IMM, J.Y., SUH, H.J. (2012). Physical and sensory characteristics of fibre - enriched sponge cakes made with Opuntia humifusa. Food Science and Technology, 47, 478-484.

[19]LEE, B.H., KIM, H.J., Yu, W.R. (2009). Fabrication of long and discontinuous natural fibre reinforced polypropylene biocomposites and their mechanical properties. Fibers and Polymers, 10, 83-90.

[20]LU, X., QIU ZHANG, M., ZHI RONG, M., SHI, G., CHENG YANG, G. (2003). Melt processable composites of sisal. Composites Science and Technology, 63,177-186.

[21] MOMINUL HAQUE, M., HASAN, M., SAIFUL ISLAM, M., ERSHAD ALI, M. (2009). Physical- mechanical properties of chemically treated palm and coir fiber reinforced polypropylene. Bioresource Technology, 100, 4903-4906.

[22] MÜLLER, M., CIDLINA, J., DĚDIČOVÁ, K., KROFOVÁ, A. (2015). Mechanical properties of polymeric composite based on aluminium Microparticles. Manufacturing Technology, 15, 624-628.

[23]POOLE, A.J., CHURCH, J.S., HUSON, M.G. (2009). Environmentally sustainable fibers from regenerated Protein. Biomacromolecules, 10, 1-8.

[24]SHARIFAH, H.A., MARTIN, P.A. (2004). The effect of alkalization and fiber alignment on the mechanical and thermal properties of kenaf and hemp bast fiber composites: Part 1 - polyester resin matrix. Composites Science and Technology, 64, 1219-30.

[25]TSEHAYE, Y., KEBEBEW, F. (2006). Diversity and cultural use of Enset (Enset ventricosum (Welw.) Cheesman) in Bonga in situ Conservation Site, Ethiopia. Ethnobotany Research and Applications, 4, 147 - 157.

[26] VALÁŠEK, P. (2014). Mechanical Properties of Epoxy Resins Filled with Waste Rubber Powder. Manufacturing Technology, 14, $632-637$.

[27] VINCENT, H., WIERSAMA, J., KELL, S., FIELDER, H., DOBBIE, S., CASTANEDA-ALVAREZ, N.P., GUARINO, L., EASTWOOD, R., LEON, B., MAXTED, N. (2013). A prioritized crop wild relative inventory to help underpin global food security. Biological Conservation, 167, 265 - 275.

[28] WAMBUA, P., IVENS, J., VERPOEST, I. (2003). Natural fibres: can they replace glass in fibre reinforced plastics? Composites Science and Technology, 63, 1259-1264.

[29] YIRMAGA, M.T. (2013). Improving the Indigenous Processing of Kocho, an Ethiopian Traditional Fermented Food. Journal of Nurition and Food Science, 3, 1 - 6. 